\title{
ETHNICAL AFRO TOURISM IN BRAZIL
}

\section{POR LUIZ TRIGO E ALEXANDRE PANOSSO}

RESUMO O artigo desenvolve uma discussão teórica sobre o turismo étnico afro no Brasil. A temática somente recentemente tem merecido a devida atenção dos estudiosos, motivo pelo qual se justifica a abordagem. Os objetivos são três: 1) revisar a história das culturas afros no Brasil; 2) identificar as forças que garantem o respeito a essas identidades e; 3) analisar como os destinos afro devem ser trabalhados neste contexto. A metodologia empregada é a revisão teórica dos textos que abordam a cultura afro brasileira, tendo como pano de fundo da discussão os delineamentos dos estudos culturais. Conclui-se que o produto turístico com base na cultura afro é um produto viável no Brasil, porém deve primar pelos quesitos de respeito, alteridade, ética e valorização de todas as culturas envolvidas no processo.

PALAVRAS-CHAVE Turismo Afro Culturas Afro Estudos culturais $\underline{\text { Brasil }}$

\section{ETHNICAL AFRO \\ TOURISM IN BRAZIL}

ABSTRACT The article develops a theoretical discussion on the ethnical Afro tourism in Brazil, a theme that just recently has deserved due attention from scholars, and is the motive to which this approach is justified. It has three objectives: 1) to review the history of Afro cultures in Brazil; 2) to identify forces that assure respect for this identities and, 3) to analyze how Afro destinations must be worked within this context. The methodology used is the theoretical reviewing of texts that approach the Afro Brazilian culture, having as background the discussion of cultural studies delimitation. One concludes that the touristic product based upon Afro culture is a viable product in Brazil, although it may prioritize issues like respect, otherness, ethics and valuing of all cultures involved in the process.

\section{KEY WORDS}

Afro Tourism

Afro Cultures

$\underline{\text { Cultural Studies }}$

Brazil

Over the last decade (2000-2010), Brazilian tourism has gone through several economical, social and cultural changes. One of the characteristics of tourism planning and operation in the country has been the acknowledgment of more 
specialized and delimited market segments, both as a potential to be explored and a product ready to be offered. A country with continental characteristics like Brazil has varied geography, diversified history and pluralistic and complex cultures. Therefore, the development of new itineraries or themes implies in rigorous analysis of these segments to take advantage of their ethnical and cultural wealth and to avoid stereotypes or prejudices. There are three specific examples, among many, of how official policies have systematically and deliberately stimulated ethnical Afro tourism in Brazil. Firstly, in 2006, the Ministry of Culture and the Institute of National Historical and Artistic Patrimony (IPHAN) published, under coordination of Martins Ramassote, the book Os tambores da Ilha (The Island's Drums). It is a study on "Maranhão's popular cultural manifestations", the Creole's Drums ... is a kind of expression from an Afro-Brazilian matrix that involves circular dancing, singing and drums percussion" (RAMASSOTE, 2006, p. 16). The text is one of the theoretical basis that offer subsidies to Afro ethnical tourism in the state of Maranhão, southern part of Brazil, one of the most significant cultural poles in the country.

Another example is the guide organized by the Bureau of Tourism of Bahia State, entitled Turismo étnico Afro na Bahia, published in 2009, and followed by the organization of I National Seminary of Ethnical Afro Tourism, in August 2010, in Salvador. This document is an important conceptual and historical reference. Its content comprises all main ethnical Afro groups of Bahia: sudaneses (ioruba, daomeanos, mina), bantus of the angola-congolês group, bantus from Moçambique's Counter-Coast, muslims (peuhls, mandingas, haussa), who were breeders and farmers, men of forest and savanna, from totemic civilizations, matrilinear and oatrilinear (BASTIDE, 1971, p.67-68). The text also includes culture and religions of African matrix; religious and popular feasts; quilombos and the black resistance during slavery; touristic circuits and existing itineraries as well as a complete calendar of activities, ceremonies and feasts of Black Bahia.

The third example is the circuit Rota da Liberdade (Route of Freedom) which promotes the rescue and valuing of black history and culture in the country through the development of tourism in Vale do Paraíba, Litoral Norte and Serra da Mantiqueira, in the borders between the states of São Paulo and Rio de Janeiro. The members of traditional black communities are inserted in the process of knowledge and tourism management and in generation of work and income. It is a route marked by old Vale do Paraíba coffee farms and remnant quilombolas, an opportunity of authentic experiences and contact with the way of life and the identity of Afro-Brazilian ethnical groups. These ingredients have given to the circuit Rota da Liberdade: Dever de Memória da Diáspora Africana no Brasil (Route of Freedom:Duty of Memory of African Diaspora in Brasil) a place of worldwide fame. According to Desafio em 
Geoturismo (Challenge in Geotourism) 2009, organized by the National Geographic Society and Changemakers of Ashoka, the circuit is among the ten most innovative programs of sustainable travelling in the world (www.abolitions.org).

The critical problem that precedes any Afro ethnical planning or tour organization in Brazil has to do with the right understanding of black cultures' complexity, by virtue of their several African origins. As there is no "native culture" in Americas, as shown by the plurality of indigenous people in the continent, there is no "black culture" either, for "the black people introduced in Brazil belonged to different civilizations and came from several regions in Africa. However, they were tied to certain forms of familial or tribal organization and special biogeographical means, tropical forest or savanna, peasant or communitarian structures. The African slaver traffic has violated all this." (BASTIDE, 1971, p. 30).

Therefore, the Afro ethnical tourism depends on a historical, cultural, social, economic and political understanding of negritude in Brazil, specially of what meant the brutal process of slavery which lasted from the early sixteenth century until 1888, when it was ended by the Golden Law. Brazil was the last nation in the Western world to abolish black slavery, productive basis of colonial system of plantation (patriarchal, enslaver, landowner, monoculture for exportation) and of all Empire's agricultural period (1822-1889).

Evidently such process provoked fractures in Brazilian society that were, bit by bit, understood and overcame, as the country strengthened democratic pluralism and the notion of citizenship and diversity.

\section{METHOD}

The valuing of Afro cultures in Brazil is something recent, since during centuries, ethnic groups and black culture were characteristics of human beings not considered as citizens or holders of the same rights of white elites, consequence of an enslaver system that existed in the country since its origins until late Nineteenth century. Even after slavery abolition, during the republican period, the Brazilian dominant social structure kept clear distinction between elites and popular classes. In case of tourism, the development of Brazil's area since the beginning has been exclusively linked to high and middle classes, who could afford prominent consumption. This initially meant the tourism of aristocratic elites who stayed at the few luxury hotels in the country, during the decades of 1930/1940, enjoying thermal, climatic tourism and casinos. At a later time, with the implantation of 
automobilistic industry (decade of 1950), middle classes started having a second house in the beaches, mountains or countryside. A fragile democracy was shaked by conservative dictatorships (1930-1945 e 1964-1985) that kept, despite the popular, nationalist and demagogic speech, the economic and cultural hegemony of elites, now enlarged with state technobureaucrats.

A rich period of artistic, cultural and educational creation in the decade of 1960, with critical and conscious valuing of popular values and social pluralism was interrupted by military dictatorship in 1964 and during twenty years Brazil was under a kind of xenophobe regime, narrow minded and with a worldview restricted to dogmas typical of Cold War periphery (1947-1991). Only from the mid-decade of 1980, and after the country's redemocratization, interests- academic, commercial and political - start to be seen, on studies of genre, ethical, sexual and cultural minorities within the context of pluralism and diversity that mark freer societies, with ethical and communal awareness directed to all segments of population. Finally, over the last Twentieth century decades, the Afro-Brazilian culture emerges in several points of Brazil and slowly becomes an acknowledged and respected national segment, structuring cultural and artistic products, media insertions, specific laws against decriminalization, politics of their own and itineraries and touristic destinations that allow valuing and identifying the many ways which framed not only the Afro-Brazilian cultures, but also how they articulated themselves in the formation of the complex national culture. Therefore, the purpose of this analysis is:

1. To review the history of the beginning of the acknowledgement of Afro-cultures in Brazil, through academic texts and official documents from the Twentieth century, having as parameter the analysis of cultural studies, developed during the last century (WILLIAMS, 1950, 1958, 1976);

2. To identify decisive forces within these own cultures context in order to guarantee the respect to Afro-Brazilian identities and the conquering of a pride and acknowledgement of their own;

3. To understand how ethnical Afro destinations and touristic itineraries are inserted within this context and must be worked out. This understanding is fundamental to avoid that itineraries destined to cultural minorities in general, and particularly the Afro culture, be marked by stereotypes, by the stigma of "exoticism" or by reproduction of concepts or inaccuracies that marked the life of black people in Brazil. The ethnical Afro tourism should be an activity oriented and conceptualized by awareness and valuing of these cultures, aiming at not only commercial objectives, but the 
permanent construction of citizenship and of national cultures and identities.

\section{THE AFRO ETHNICAL TOURISM IN BRAZIL}

The understanding of another culture depends on availability, otherness and scientific method in order to know how this culture would manifest itself and how it interacted with others along space and time. Brazil is characterized by a large territorial extension, by a quantitatively considerable population (over 180 million inhabitants) and by complex cultures, due to mixture and companionship of several ethnic groups in its history. "Interpenetrations of civilizations do not constitute a new phenomenon, linked to the Nineteenth century European expansion. On the contrary, one can say that all mankind history is a history of contact of fights, immigration and cultural fusions." (BASTIDE, 1971, p. 23). The large Brazilian cities, where the black cultural manifestation is highly significant, offer challenges to its interpretation. Jorge Amado for instance, sees Salvador as
[...] a land where all is mixed up and melted, no one is capable of distinguishing the right from the absurd, establish limits between strictness and deception, between reality and dream. In the lands of Bahia, saints and enchanted ones abuse of miracles and witchcraft, and Marxists ethnologists are not scared when they see the image of a catholic altar turns into a graceful woman mulata as night falls (AMADO, 1988, p. 44).

Bahia possesses a very long fame sung in literature. One of the first poets to sing the land with romanticism, but also with sarcasm was Gregório de Matos Guerra (1636-1695), who immortalized local culture in his verses, both its qualities and flaws.

Besides novelist Jorge Amado, other writers are important to understand local culture. João Ubaldo Ribeiro narrates the life of a black family from Bahia, living in the island of Itaparica and in the Recôncavo, an area close to Salvador, generation by generation, during almost three centuries. It is one of his best books, entitled Viva o povo brasileiro (Hail the Brazilian People) (1984), that critically analyses- and with a good mood - the everyday regional facets which still influence Bahian contemporaneity.

The calendar of feasts in Salvador takes place in midsummer, starting with the feast of Iansã (Oyá/Saint Bárbara), on December 4; going through feast of 
Nossa Senhora da Conceição da Praia (08/12); the processions of navigators on January 1 ; the feast of Iemanjá $(02 / 02)$ and finishing with carnival, a multifaceted event with blocks, electric trios, independent groups and millions of people on the streets, squares and avenues of the city. Not to mention that all year around, every day of the week there is at least one festivity in the fixed calendar which involves pageants, masses, benedictions, music or gastronomy. All these feasts have a thematic structure and aesthetics that are often placed between the Christian catholic context and candomblé's manifestations or other religions from Afro origin.

To a careless observer, the popular feasts of Salvador appear to look the same. They belong to the same summer feasts cycle of time. One can even say that in Bahia, for each and every feast of a catholic saint there is a procession, washing of the church stairs, bath with perfumed water and the come and go of happy people who, at the same time, pay promise, drink and smear themselves with palm oil, sing and dance after the electric trio" (COUTO, 2010, p. 93).

Of course there are differences, and they are significant.

The text of Afro ethnical tourism in Bahia lists the following feasts of Salvador (not to mention religious catholic feasts that are in another calendar of Bahia and the other feasts of others regions in Brazil):

\section{Festa da Irmandade de Nossa Senhora da Boa Morte (Feast of the Brotherhood of Our Lady of Good Death) - was born at senzalas, approximately 150 years ago;}

Congada - mixture of African heritage with Portuguese culture, its origin is in Congo, 1482;

Lindro Amor - it is an intercessory procession in the feasts of Our Lady of Purification or Saint Cosme and Damião, a tradition from the time of slavery;

Nego Fugido - it is a feast, variation of quilombo, and is at least one century old;

Zambiapunga - procession of masked men who go out at daybreak, dedicated to the supreme god of candomblé of Angola;

Bembé do Mercado - it takes place every May 13, since 1889 (date when princess Isabel signed, in 1888, the law which extinguished slavery in Brazil), to celebrate the end of slavery. 
As for music, the black people influence is heard in batucada, in samba, in samba-reggae, or in Axé Music. The anthropologist Goli Guerreiro did a deep study on Bahian musicality in her doctorate thesis (Universidade de São Paulo - USP, 1999), entitled A trama dos tambores (The plot of drums), where she analyses more specifically the samba- reggae, a musical movement that attracts controversy of musicians, scholars of Afro cultures and anthropologists. Goly nowadays writes a blog (www.terceiradiaspora.blogspot.com/) where she openly explores the worldwide situation of Afro cultures and presents an unedited concept of "Third Diaspora", a concept more aesthetical and mediatic rather than merely sociological:

Grafitti in Salvador; multimedia performance in Harlem; hairdressers in Brixton, London; recording studios in Kingston; literary coffees in Fort de France; Cuban santeria; carnival in Port of Spain; restaurants in Lisbon; bands Afropop in Paris; arts in Dakar; Nigerian films; Kuduro in Luanda; festival of vodum in Benin. The Third Diaspora deals with the present of black people cultures and goes through the repertoire of Atlantic cities in several forms of narratives in order to recognize the circuit of communication which allows displacement of ideias, attitudes, sounds, images, fashions, ideologies - here called third diaspora, a technological-digital way that allows displacement of cultural signs. The first diaspora, by means of slavery, took place with historical displacements of black people traffic and the return of former slaves to Africa. The second one, by means of voluntary displacements with migration of Jamaicans to London; Puerto Ricans to New York; Benineses to Paris; Cape Verdean to Lisbon an NY; Angolans to Brazil, etc. The third diaspora is the displacement of signals induced by the circuit of technological/electronical information such as discs, movies, hairs, slogans, gestures, fashions, flags, rhythms, icons, ideologies, etc. It is a vision that invests in the circuit of black people diaspora which has made itself possible with the electronicdigital globalization and connects citieslike Salvador, Kingston, Havana, New York, New Orleans, London, Lisbon, Dakar, Luanda, etc.(Source: www.cult.ufba.br/enecult2009/19287.pdf).

Another important author is Josué Montello, who analyses in his novels the city of São Luis do Maranhão and its outskirts, as a colorful web of races and cultures, here drums mine live together with liturgical songs from Catholicism, where even the holy Spirit gains a color incarnated in the form of a dove who is everything but childish. His novel, Os tambores de São Luís (The drums of São Luis), describes the route of Damião, a brilliant black young man, born slave in a region that, during the Nineteenth Century still didn't tolerate racial equality in all levels (Damião, despite of his immense 
intellectual capacity, cannot be ordained priest after long years of study in a catholic seminar because of the color of his skin), although it had centuries of participation in the community.

It is not only the black people culture which has its mysteries and subtleties. The northern interior culture gained in Ariano Suassuna (Romance da Pedra do Reino [Novel of Stone of the Kingdom]) a wealth of details and outlines which exemplify what the author qualifies of "official Brazil" and "real Brazil". This real Brazil of northern inlanders is the same of black people and mulatos, poor white people, Indians and immigrants subjected to everyday fights for survival and acknowledgement of their citizenship rights.

In São Paulo, in the case of Route of Freedom, the circuit promotes the rescue and valuing of black people history and culture in the country through tourism development in Vale do Paraíba, Northern Shore and Serra da Mantiqueira. The members of black communities are inserted in the process of knowledge and tourism management and in generation of jobs and income. The project also counts on the implementation of accessibility to handicapped people in itineraries.

The proposal is of a trip through coffee cicle, telling the saga of the Africans, his history, culture, gastronomy and religiosity, via a route through old coffee farms of Vale do Paraíba and remnant quilombolas. The intinerary aims at providing deep and authentic experiences and establishing contact with the way of life and the identity of Afro-Brazilian ethnical groups. These ingredients have given to the circuit Route of Freedom: Duty of Memory of African Diaspora in Brazil a place of worldwide prominence.

The work is done together with traditional Black Communities of the region like Cia de Moçambique Unidos a São Benedito, from the city of Taubaté and the Associação Quilombolas do Tamandaré (Jongo de Guaratinguetá), besides partnerships in studies on African Diaspora in institutions like IEV (Instituto de Estudos Valeparaibanos), Museu Frei Galvão and Arquivo Histórico de Taubaté. This is the second Project of Memory Tourism which follows orientations of Unesco in its worldwide project "Route of the Slave". The first one is developed in France ("Touristic Route of Abolitions":

www.abolitions.org).

\section{BRAZIL WITHIN AFRO INTERNATIONAL CONTEXT}

Ethnical tourism is well defined by Brazilian official policies. According to 
Ministry of Tourism, in its conceptual landmarks,

Ethnical Tourism is compounded of touristic activities resulting from authentic experiences in direct contact with ways of life and identity of ethnical groups. One searches to establish a close contact with a host community, to participate in their traditional activities, to observe and to learn about their singular cultural expressions, lifestyles and customs. Many times, such activities can be articulated as a search for the origins of the tourist, in a return to his/her ancestors' traditions. Ethnical tourism involves representative communities of European and Asian immigration processes, indigenous communities, quilombolas communities and other social groups who preserve their ethnical legacies as guiding values in their way of life, knowledge and behavior.(Source:

www. turismo.gov.br/export/sites/default/turismo/o ministerio/public acoes/downloads publicacoes/Marcos Conceituais.pdff).

If well planned, implemented and administrated, it can promote the tourist interaction with local population; of tourists themselves, in the local context; and of local inhabitants among themselves, in relation to tourism and tourists.

These are relations that must promote building of mutual respect and tolerance, the base of citizenship in developed countries and which encompasses education and culture within an organized civil society. Therefore, ethnical tourism inserts itself in what could be understood as democratic, pluralistic, complex, multiethnic and multicultural societies.

In Brazil, studies on black awareness are recent and had their origins little more than one century ago. The first text published was $L$ 'Animisme fétichiste des négres de Bahia(Paris, 1900), written by the physician Nina Rodrigues and was a landmark of sociology about black people in Brazil. In the decade of 1950, there were studies about the traffic, slavery and abolition, under a historical and economic perspective, besides anthropological studies on the physical and cultural differences of several groups of black people who came from Africa.

But it was only after the decade of 1970 that studies appeared, based on black people own awareness of their identity, inclusion and social participation. With the redemocratization of the country (1985), public policies emerged, focused on specific groups in order to strengthen inclusion and breaking of prejudices, and also affirmative actions, to assure visibility and rights to all ethnic groups, cultures and lifestyles. 
Accordingly, a fundamental writer is Carolina Maria de Jesus (1914-1977). Black, poor and slum dweller, born in Sacramento (Minas Gerais State), Carolina de Jesus wrote Quarto de despejo (Garbabe Dump), a text of reference for cultural studies in Brazil. Carolina knew since childhood discrimination in an elitist society of that time, due to her condition of slaves' grand-daughter, black and poor. She spent her childhood and adolescence roaming through cities of Minas Gerais and São Paulo countryside in search of survival. In 1937, with 23 years old, she lost her mother and went to São Paulo, looking for better opportunities. Among informal jobs and domestic tasks, the yet-to-be-writer dreamed of literature. Years later, living in a slum and collecting papers to survive, Carolina wrote constantly in sheets found in the garbage.

Acknowledgement came by chance, when a reporter of "Folha da Noite" newspaper, Audálio Dantas, was writing a news story about Canindé slum (1958). Among the shanties of the slum, the journalist met Carolina, who showed her texts to him. It was her journal, written in old notebooks, describing the hard reality in which Carolina and other slum dwellers of Canindé were living in. The young reporter was impressed with the reading and on May 19 1958, the newspaper published part of the text. In 1960, the work was published in full, with an initial printing of 10000 copies. At the book signing night 600 were sold, and by the end of the year sales reached 100000 copies. "Quarto de Despejo" was published in 13 languages, in more than 40 countries. This was a significant landmark of inclusion in Brazilian literature, where poverty was shown not only by academic texts, but by someone who lived and suffered their illnesses and consequences. The elites offered resistance to her literary career, just for the fact she was poor and out of artistic and literary local circles.

Contemporary tourism, conscientious, should nourish itself exactly from this diversity, the many possibilities of inclusion, solutions that propose sustainability and "authenticity" in cultural experiences lived in other communities, ethnic groups and cultures.

The ethnic-Afro tourism directly encompasses other cultural aspects besides feasts and dances such as gastronomy, cultural centers, museums and a whole network of formal and informal relationships that involve local community and, eventually, the tourists. In Brazil, one of the main specific works on gastronomy and orishas is entitled Comida de santo (Food of saint), written by Maria Helena Farelli (2000). Another important book is Santo também come (Saint also eats), (1979) by Raul Geovanni da Motta Lody, an anthropologist and museologist, specialized in Afro-Brazilian studies. 
(palm oil), which is mixed with other spices such as ginger, peanuts, chestnut, and cooked in coconut milk, giving to the cuisine its own style, especially in Bahia. Dishes such acarajé, moquecas, bolinho de estudante, vatapá, caruru, quindins and cocadas are some of the local delights. In other states of Brazil where Afro culture is significant, there is a specific gastronomy, with regional dishes equally relevant.

In other countries, the influence of African cookery is also remarkable, like in New Orleans (USA); Caribbean, where Carla Guerrón-Montero studies the so-called Afro-Antillean Cuisine; or the Afro-Lusitanian Cuisine, extant in Moçambique, South Africa. In Brazil, the researcher Mercia Maria Aquino de Queiroz published her doctorate thesis Turismo de raizes na Bahia [Tourism of Roots in Bahia] (Salvador: UFBA, 2008), where she analyses these influences and cultural effects, so rich and complex, in Brazilian society. The researches with cookery ingredients are part of a larger research which involves seeds, plants, flowers, fruits and all that Brazilian tropical flora can offer to feeding, medicine, enchantments or poisons. The Fundação Pierre Verger lists twenty-five titles in its section of "Botânica" in Brazil (www.pierreverger.org/fpv/index.php? option=com content\&task=view\&id=139\&Itemid=537), not to mention specific sections about Africa, France and other countries in the world.

The classic on African plants is the book by Pierre Fatumbi Verger, entitled Ewé - O uso das plantas na sociedade Ioruba [Ewé - the usage of plants in Ioruba society] (1995), a guide in detail on the characteristics and proprieties of several plants, important for Afro-Brazilian religions.

Black people culture is also found in museums which go through specialized guardianship of members of Afro-descendents communities and offers a collection for observation, research and awareness to citizenship and culture. In Brazil, two museums stand out: the Museu Afro Brasil, located in São Paulo, at Ibirapuera park, and the Museu Afro-Brasileiro da Bahia, located in Salvador.

In the United States, country where racism and racial conflicts were more explicit than in Brazil, there are many important museums: Afro-American Museum, in Boston and Nantucket; California African American Museum, in San Francisco; African Art Museum, in Washington DC and the African American History and Culture Museum, also in Washington DC, which is still part of the American History Museum, but will have its own building over the next years. These museums of the North-American capital are part of the complex Smithsonian Institution, one of the largest touristic attractions of the United States. 
Ethnical Afro tourism appears in Brazil, in the context of an increasing valuing of black cultures who migrated to America during European colonial slavery and mixed to other cultures, either European or native Americans, forming new social, economic and cultural configurations. Roger Bastide identifies, over the history of black people' fight for civil acknowledgement,

a kind of antagonism between two solutions to the problem of Brazilian black people, the cultural solution and the political solution; where the first one has triumphed, politics has not had presence, and where the second has prevailed, the previous cultural resistance has soon been nullified. (BASTIDE, 1971, p. 74).

Ethnical tourism managers need to be aware that it is inserted into a historical hillside and an economic, cultural and social space which requires caution and attention to the population that has been submitted for centuries to an unequal treatment provoked by systematized racism in an enslaver regime that has left visible and invisible scars in Brazilian society.

Because of democratic stabilization and conquests in the fields of citizenship, pluralism and diversity along with other excluded or marginalized segments of society, cultures of black origin gained room and visibility, participating more and more of national life in all levels. The problem analyzed by Roger Bastide needs to be considered by tourism. The sector must help both in the field of public policies of tourism and social inclusion, and in the elaboration of policies - public or private - in the field of arts and culture. So it is possible to minimize this dichotomy between politics and culture through leisure, sports and tourism practices that take into consideration the participation of communities involved in several projects that guarantee sustainability natural and cultural - inclusion, and a fair distribution of income and profits.

The words Edward Said uses to exemplify prejudice in relation to eastern people fits perfectly to black people:

along with all other peoples appointed, in many ways, as delayed, degenerated, uncivilized and retarded, the eastern people were seen within a structure built from biological determinism and moralpolitical censorship. Therefore, eastern people were associated to elements in western society (delinquents, insane, women, poor) who had in common an identity better described as regrettably foreigner. (Said, 2007, p. 281).

The black people were foreigners in American enslaver societies, the natives 
were seen as foreigners before the real foreigner who was the European, but saw himself imbued of a holy and civilizing mission: to take the true Christian religion to other peoples and to spread science, good managing and progress.

During the Nineteenth century, Darwinian and phrenologist anthropologists structured racist theories, totally without scientific foundation, to justify the supposed superiority of western civilization, Christian and Eurocentric, over other peoples. These racist theories were enriched by compared linguistics and by the philology of that time (SAID, 2007, p. 148).

The echoes of these ancient prejudices are still heard in everyday interstices of the globalized world, or in the speeches of extreme right-wing racist parties that organize themselves because they miss Nazi-fascism, or in the old imperial projects, either the European colonialism or the capitalist imperialism, and in the Soviet or Chinese socialist ideology.

Observing the increasing valuing of Afro culture in Brazil and in the world, the structuring of touristic itineraries and destinations based especially in ethnic groups and in culture, a questioning appears on what has taken a marginalized, stigmatized culture, considered inferior, to be gradually acknowledged and respected. This acknowledgement and respect come from inside out, that is, the communities themselves, of African ascendancy, became proud of their roots and assumed their ethnical and cultural characteristics: style of haircut, clothing, music, food, language, postures, tradition, imagery. However, was there something strong enough to catalyze and encourage values that transcended secular prejudices that kept black people and mulatos on an inferior platform in Brazilian society? The answer is yes and, according to several scholars, the motive is religious.

The maintenance of African religions should be seen definitely in the dualism of opposed classes. The black people cannot defend themselves materially against a regime where all rights belonged to white people; so they took refuge in mystical values, the only ones which could not be taken from them. And they fought with the only weapons left, the magic of sorcerers and the manna of their warrior divinities. But, naturally, this new orientation given to collective representations brought from Africa would alter their meaning (BASTIDE, 1971, p. 96).

It was this same religious feeling which triggered the revolution of slaves in Haiti (initiated in 1791, culminated with France's independence in 1804, and considered the onlyvictorious rebellion of slaves since western antiquity) as well as marked Afro religions in southern United States, Caribbean and in several points of South America. 
But what about the work of Christian evangelization made by Franciscan, Dominicans and Jesuits missionaries with Indians and black people?

Catechism remained superficial: Catholicism superimposed itself upon African religion during the colonial period, but did not replace it. Under the shadow of the cross, the chapel, the mill and the urban church, the ancestral cult continued, which took Nina Rodrigues to declare, in the end of the enslaver period, the illusion of slavery (BASTIDE, 1971, p.181).

These animists African religions received in Brazil the name of "candomblé, with well defined and local characteristics. In these religions, there is a primordial god who uses orishas, ancient living creatures who acquired powerful energies to communicate with humans. In Africa, the orisha is familial, all families have their orishas, and the oldest member of the household is their priest. There, public cerimonies take place with all orishas. The yam feast, for instance, main African food, starts right after the harvest, with an offering to orishas before it is distributed to the people.

In Brazil, all cadomblé yards have several orishas; in Africa each yard has only one orisha. These religions suffered prejudice in the past and until today they are stigmatized by some evangelical groups. The great strangeness comes from Christians, because of the immolation (killing of animals), but jews and muslims have this practice. Some jewish groups kill animals in the feast called Kaparot, as purging of their sins. Muslims, in the end of Ramadã, kill lambs at Eid-Al-Adha, feast of sacrifice of Islam, where they sacrifice rams, also to purge their sins. The sacrifice of the lamb and of other animals in the temple of Yahweh is described normally in several Old Testament books.

To Tasso Gadzanis, vice-president of São Paulo Turismo and deep studious of Afro- Brazilian religions, the valuing and the respect of black cultures in Brazil is due to Candomblé, for it assures a mystical side which attends popular longings. The candomble is the psychological answer to certain personal problem. All is linked to the ancestor, by whom there is a great respect and this creates a spirit of historical awareness and collectivity which allows the dignity of the persons.

There is no agreement on the number of gods in the African pantheon. Old European authors considered 402 Orishas of candomblé (Mãe Menininha de Gantois would call them Enchanted Ones). In Brazil approximately 20 are worshipped. Roger Bastide compares the names of divinities in the states of Bahia, Pernanbuco, Alagoas, Rio Grande do Sul, Rio de Janeiro, Pará and Maranhão and in Cuba and Haiti and describes a total of 22 divinities (BASTIDE, 1971, p 364-369). Reginaldo Prandi enumerates 16 Orishas of 
queto nation.

Ethnical Afro tourism should consider its roots which are animists, brought from Africa and influenced by Brazilian natives and by the European Catholicism. To respect religions of African origin is the base, the platform from where it is possible to structure planning, operation and management of touristic itineraries and destinations in these communities with a history at the same time so rich and hard. The key for valuing black cultures in Brazil and in other places of Americas includes African religions and their articulation with other cultures, their powerful and playful influence, so different from the melancholy or gravity of spiritualists, evangelicals and some catholics. African animism mingled with popular Catholicism thanks to their chants, dances, colors and profusion of saints who compete with a central divinity, in turn is triple and with a mother equally saint and venerated.

The French anthropologist Pierre Fatumbi Verger in his work had the ability of finding common points between Brazil and Africa, offering contacts and exchanges that enriched both sides of the Atlantic, being respected for this and accepted by the people of the Saint, insomuch he inserted an African name "Fatumbi" among his original French names.

Ethnical Afro tourism in Brazil depends on how Brazilian society is understood, and how to work ethnical, sexual, religious and cultural diversity, having as an advanced hillside the complex inclusive and participative democracy proposed to all social segments, including the ones historically marginalized and excluded. Finally, Afro religions have aesthetics, a cultural and historical density comparable to other religions established as the several Christians hillsides, Judaism, Islamism, and eastern religions. To respect this historical and geographical, ethnical and cultural framework is to collaborate to a wider and inclusive tourism, a more tolerant and participative society, where citizenship does not belong to elites or missionary groups anymore, but is shared by all society.

\section{PRINCIPAL AUTHORS AND STUDIES ABOUT CANDOMBLE IN BRAZIL}

This short list not intended to be a "canon" of African studies in Brazil, but a guide to mark the main topics and writers who formed the main body of these studies. 
1900 - Nina Rodrigues - O animismo fetichista dos negros baianos.

Beginning of the XX Century - Manuel Quirino - made some amateur studies.

1906 - João do Rio (Paulo Barreto) - As religiões do Rio.

1930/1950 - Artur Ramos and Edson Carneiro research about Bahia State. Gonçalves Fernandes, Vicente Lima and Pedro Cavancante research about Pernambuco State.

1943 - Melville J. Herskovitz -researches about "batuque" in Rio Grande do Sul State.

1947 - Manuel Nunes Pereira - A Casa das Minas: contribuição ao estudo das sobrevivências do culto dos voduns, do panteão Daomeano, no Estado do Maranhão.

1947 - Octavio da Costa Eduardo studies the Tambor-de-mina - Maranhão State.

1950 - René Ribeiro and Waldemar Valente study Pernambuco State.

1957 - Pierre Verger - Note ssur lê culte des orisas et vodun à Bahia, la Baie de touts les saints au Brésil et à l'anciénne Côte des esclaves en Afrique.

1961 - Candido Procópio Ferreira de Camargo studies Kardecismo and Umbanda.

1958 - Roger Bastide presents Le camdoblé de Bahia (in Brazil only in 1978). Candomblé has now sociological status.

1960 - Roger Bastide presents As religiões africanas no Brasil (in Brazil only in 1999).

1970 - Renato Ortiz publishes A morte branca do feiticeiro negro and Yvonne Maggie publishes Guerra de orixá.

1972 - Marco Aurélio Luz and George Lapassade publish O segredo da macumba.

1975 - Peter Fry and Gary Nidel Howe, publish Duas respostas a aflição: umbanda e pentecostalismo. Debate e Crítica - Revista quadrimestral de 
Ciências Sociais.São Paulo, HUCITEC, n. 6, 1975.

1975 - Ruth and Seth Leacock publish The spirit of the deep.

1976 - Anaíza Vergolino e Silva presents the thesis at the Unicamp (São Paulo), O tambor das flores.

1976 - Juana Elbein dos Santos publishes Os nagô e a morte.

1981 - Pierre Fatumbi Verger publishes the classic Orixás: deuses iorubás na África e no Novo Mundo.

\section{bibliografia}

AMADO, J. O Sumiço da Santa: uma história de feitiçaria. Rio de Janeiro: Record, 1988.

BASTIDE, R. As religiões africanas no Brasil. 2. vol. São Paulo: Pioneira/Edusp, 1971.

COUTO, E. S. Tempo de festas. Salvador: EDUFBA, 2010.

FERELLI, M. H. Comida de santo. Rio de Janeiro: Pallas, 2000.

FUNDAÇÃO PEDRO CALMON. Turismo étnico afro na Bahia. Salvador, 2009.

JESUS, C. de. Quarto de despejo. São Paulo: Francisco Alves. 1960.

GUERREIRO, G. A trama dos tambores. Universidade de São Paulo: FFLCH, 1999.

LODY, R. G. da M. Santo também come. Rio de Janeiro: Pallas, 1979.

MONTELLO, J. Os tambores de São Luís. Rio de Janeiro: Nova Fronteira, 2005.

PRANDI, R. Os príncipes do destino - histórias da mitologia afro-brasileira. São Paulo: Cosac Naify, 2001.

QUEIROZ, M. M. A. Turismo de raízes na Bahia. Salvador: UFBA, 2008. 
RAMASSOTE, R. M. Os tambores da ilha. Brasília: IPHAN, 2006.

RIBEIRO, J. U. Viva o povo brasileiro. Rio de Janeiro: Nova Fronteira, 1984.

RODRIGUES, N. L'Animisme fétichiste des négres de Bahia. Paris: Reis e Companhia, 1900.

SAID, E. W. Orientalismo. São Paulo: Companhia das Letras, 2007.

SUASSUNA, A. Romance da pedra do reino. Rio de Janeiro: José Olympio, 1971.

VERGER, P. F. Ewé - O uso das plantas na sociedade Ioruba. São Paulo: Companhia das Letras, 1995.

VERGER, P. F. Orixás. Salvador: Corrupio, 2002.

WILLIANS, R. Reading and Criticism, Man and Society Series. London: Frederick Muller, 1950.

WILLIANS, R. Culture and Society. London: Chatto and Windus, 1958.

WILLIANS, R. Keywords. Fontana Communications Series, London: Collins, 1976. 